\title{
Analysis of Body Posture using Rapid Entire Body Assessment (REBA) and Rapid Upper Limb Assessment (RULA) to Improve the Posture of Sand Paper Machine Operators and Reduce the Risk of Low Back Pain
}

\author{
Trio Yonathan Teja Kusuma \\ Department of Industrial Engineering, Universitas Islam Negeri Sunan Kalijaga Yogyakarta \\ J1. Marsda Adisucipto No 1 Yogyakarta 55281, Indonesia. Tel. +62-274-540971, Fax. +62-274-519739 \\ Corresponding author \\ trio.yonathan@gmail.com
}

Manuscript received: 26 September, 2019. Revision accepted: 14 April, 2020. Published: 17 April, 2020.

\begin{abstract}
The metal casting industry, Nitikan is a micro business whose production process is carried out manually. The equipment used is simple and without considering the user's health. This can be seen in the product finishing process that uses a sanding machine. The equipment is not designed according to the user's posture so the operator bends in doing work movements, of course this is very risky to experience lower back pain injuries. This study aims to analyze the work activities of the finishing process using the Rapid Entire Body Assessment (REBA) and Rapid Upper Limb Assessment (RULA) approach and design work tools that can be applied to improve work posture. The results of data processing and analysis obtained a Rapid Entire Body Assessment score on a sandpaper machine single head of 5 and a Rapid Upper Limb Assessment score of 4, the score indicates that the work position has the potential to experience a risk of low back pain, so there must be an improvement in work posture. Work posture improvement is done by designing a tool in the form of a sandpaper machine that takes into account ergonomic dimensions to reduce the risk of lower back injury. The final result after the improvement is obtained Rapid Entire Body Assessment score of 3 and Rapid Upper Limb Assessment score of 4. This shows that the risk of lower back injuries can be minimized.
\end{abstract}

Keywords: Rapid Eentire Body Assessment; Rapid Upper Limb Assessment; Low Back Pain

\section{INTRODUCTION}

The metal casting industry, Nitikan is a micro business which can be said to be the entire production process carried out by human labor. The equipment used is simple and without considering the user's health. This can be seen in the product finishing process that uses a sanding machine. The equipment is not designed according to the user's body posture so operators bend in doing work movements, of course this is very risky to experience low-back pain injuries. In addition to injuries, the process was fairly long because it took 11 minutes. This process is somewhat longer than the other processes which on average only takes 5 minutes.

Thus it is necessary to anticipate this, business owners need to pay attention to the comfort of their workers so that work health and safety are guaranteed. This can be done by adjusting workers with work methods, work processes and the work environment. This approach is known as the biomechanical approach which in this context is REBA and RULA analysis. This analysis serves to analyze the work posture is not good and the risk of low-back pain. The analysis then becomes the basis for providing solutions in the form of work postures in the form of tools to reduce these risks. By implementing this it is expected to minimize the risk of low-back pain injuries and to increase process productivity.

\section{MATERIALS AND METHODS}

\section{Rapid Upper Limb Assessment (RULA)}

Rapid Upper Limb Assessment (RULA) is the method used to estimate the risk of injury to the upper body such as the upper arm (forearm), forearm (wrist) and wrist (wrist rotation), wrist (neck), torso. By using RULA, fast and systematic results will be obtained in determining postural risk of workers (McAtamney \& Corlett, 1993). The RULA measurement method has several main applications such as:

1. Measuring the risk of musculoskeletal (muscle), usually part of a wider increase in ergonomics.

2. Comparing muscle loads (muscles) between current and modified work station designs.

3. Evaluate results such as productivity or suitability for equipment use. 
4. Train workers about muscle loads (muscles) caused by differences in work posture.

Posture with the RULA method is divided into two parts, namely group A posture consisting of the upper arm (upper arm), forearm (forearm), wrist (wrist) and wrist rotation (wrist rotation); and Group B posture consists of the neck, body and legs. The final results obtained from the two final scores for group $\mathrm{A}$ and group $\mathrm{B}$ are combined, the combined score results from group $\mathrm{A}$ and group $\mathrm{B}$ are classified into several categories. The development in the RULA method consists of three stages, namely:

1. Selection of work posture for assessment or measurement.

2. Development of an assessment system.

3. The development of a large score is converted to one of four levels of action.

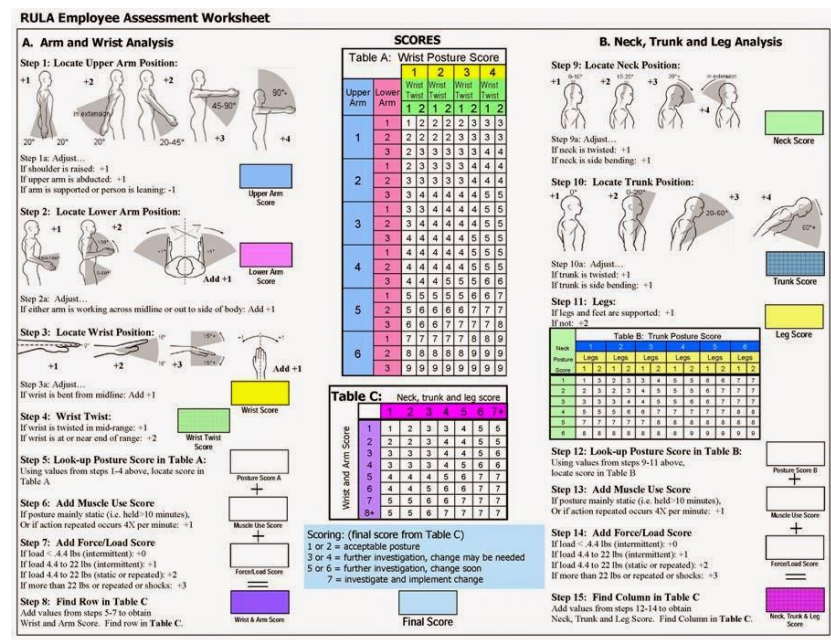

Figure 1. RULA analysis sheet (source: Mc Atamey \& Corlett, 1993).

\section{Rapid Entire Body Assessment (REBA)}

Rapid Entire Body Assessment (REBA) is an ergonomic method (Hignett \& McAtamney, 2000) developed to measure the types of postures that pose a risk to health. REBA assesses work positions on body postures such as the neck, back, arms, back of the hands and feet of the operator. REBA depends on the coupling factor, external loads supported by the body and worker's activities. Determination of REBA score manually, discussing the level of risk of work posture, starting with determining the A score for posture of the body, neck and legs plus the load score (load) and the B score for the posture of the upper arm, forearm and the hand is added with a score clutch. Both scores are used to determine $\mathrm{C}$ scores. REBA scores are obtained by adding activity scores to $\mathrm{C}$ scores from REBA values to determine the level of risk of injury. Measurement of body posture using the REBA method has six stages including:
1. Observation of body posture can be done by taking workers' posture data using video or photo assistance.

2. Selection of posture that must be done.

3. Assessment of body posture score.

4. The score calculation process.

5. Determine the results of the REBA assessment for the owned posture.

6. Check the results of the REBA assessment according to the level of action to make improvements or changes.

The REBA method can be used when an assessment of ergonomic work posture identifies the need for further analysis. The things that need to be done are:

1. All body parts used.

2. Static, dynamic, fast changing or unstable posture.

3. Modification of workplaces, equipment, training, and monitoring of worker risk behavior.

\section{RESULTS AND DISCUSSION}

The object of research was carried out in the sandpaper process section. The sanding process is carried out in 2 stages, namely coarse sanding and fine sanding. Because it only has one sanding machine, in doing these 2 steps, it has to replace the sanding eye, this causes the processing time to be longer. Another problem is the design of the sandpaper machine that does not consider the health of workers, causing workers to have to bend for a long time, causing lower back pain.

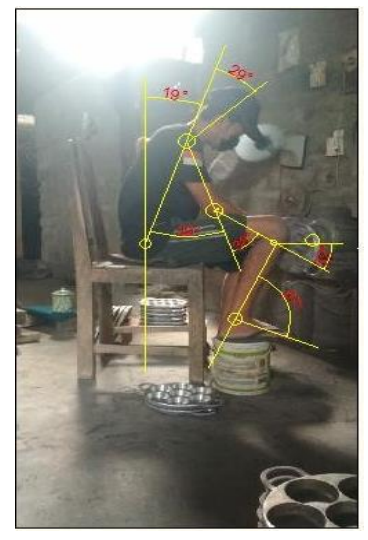

Figure 2. Sandpaper machine operator posture.

Table 1. REBA angle dimensions for sanding machine operators.

\begin{tabular}{|c|c|c|}
\hline Grup & Dimensions & Angle \\
\hline \multirow{4}{*}{ A } & Neck & 29 \\
\hline & Back & 19 \\
\hline & Knee Kaki & 87 \\
\hline & Load & 0 \\
\hline \multirow{3}{*}{ B } & Upper Arm & 39 \\
\hline & Lower arm & 38 \\
\hline & Wrist & 32 \\
\hline
\end{tabular}


Table 2. REBA score on the sanding machine operator's work posture.

\begin{tabular}{|c|c|c|c|c|c|c|c|}
\hline Group & Dimensions & $\frac{9}{80}$ & : & $\begin{array}{c}\text { Table } \\
\text { A }\end{array}$ & $\begin{array}{c}\text { Score } \\
\text { A }\end{array}$ & $\begin{array}{c}\text { Score } \\
\text { C }\end{array}$ & $\begin{array}{l}\text { Grade } \\
\text { Score } \\
\text { REBA }\end{array}$ \\
\hline \multirow{4}{*}{ A } & Neck & $29^{\circ}$ & 2 & \multirow{3}{*}{4} & \multirow{4}{*}{4} & \multirow{9}{*}{4} & \multirow{10}{*}{5} \\
\hline & Back & $19^{\circ}$ & 3 & & & & \\
\hline & Knee & $87^{\circ}$ & 1 & & & & \\
\hline & \multicolumn{3}{|c|}{ Load } & 0 & & & \\
\hline Group & Dimensions & $\frac{9}{80}$ & : & $\begin{array}{c}\text { Table } \\
\text { B }\end{array}$ & $\begin{array}{c}\text { Score } \\
\text { B }\end{array}$ & & \\
\hline \multirow{5}{*}{ B } & Upper Arm & $39^{\circ}$ & 2 & \multirow{3}{*}{3} & \multirow{4}{*}{3} & & \\
\hline & Lower Arm & $38^{\circ}$ & 2 & & & & \\
\hline & Wrist & $32^{\circ}$ & 2 & & & & \\
\hline & \multicolumn{3}{|c|}{ Coupling } & 0 & & & \\
\hline & \multicolumn{5}{|c|}{ Activity Score } & 1 & \\
\hline
\end{tabular}

For the number of scores in Table A, a result of 3 is obtained and added to a Load score of 0 because the Load weight is less than $5 \mathrm{~kg}$. Then the A score has a score of 0 because the Load weight is less than $5 \mathrm{~kg}$. Then the score $A$ has a score of 4 . From each angle of group B the table B score is generated that is equal to 3 and coupled with a coupling score of 0 because the grip is right and in the middle so that the grip on the Load is strong. Then the resulting B score is 3 . Based on the A score and the B score, it can be seen the value of the $\mathrm{C}$ score is 4 . To get the REBA score, by adding up the $\mathrm{C}$ score of 4 with an activity score of 1 , the result score is obtained 5. Based on the Risk table it is known that Reba Score of 5 indicates a moderate level of risk and work position needs to be improved.

Table 3. RULA angle dimensions for sanding machine operators.

\begin{tabular}{cll}
\hline Grup & Dimensions & Angle \\
\hline & Upper Arm & 39 \\
A & Forearm & 38 \\
& Wrist & 32 \\
& Twist & 0 \\
\hline \multirow{2}{*}{ B } & Neck & 29 \\
& Back & 19 \\
& Feet & 87 \\
\hline
\end{tabular}

Based on data processing using RULA, then the results obtained by 3 and then coupled with muscle and energy scores. Muscles have a score of 1 and a score of energy usage of 0 due to occasional loading or energy of less than $20 \mathrm{~kg}$ and retained. So as to get a $\mathrm{C}$ score in group A of 4 . While in group $B$ the results obtained in table $\mathrm{B}$ are as big as 3 then added with muscle and energy scores. Muscles have a score of 1 and a score of energy use of 0 due to occasional loading or less than $20 \mathrm{~kg}$ of energy and retained. So as to get a D score in group B of 4. Based on the scores of C and D scores obtained, the RULA value was obtained. For the $\mathrm{C}$ score in group A obtained by 4 and the D score in group B obtained a result of 4 . By looking at the grand score table based on the C and D scores, a RULA score is 4 . The score indicates that changes need to be made, figure 2 shows the operator's body position is less comfortable.

Table 4. RULA score of sanding machine operator posture.

\begin{tabular}{|c|c|c|c|c|c|c|}
\hline Group & Dimensions & Angle & Score & $\begin{array}{c}\text { Table } \\
\text { A }\end{array}$ & Score C & $\begin{array}{r}\text { Score } \\
\text { RULA }\end{array}$ \\
\hline \multirow{6}{*}{ A } & Upper Arm & $39^{\circ}$ & 2 & \multirow{4}{*}{3} & \multirow{6}{*}{4} & \multirow{12}{*}{4} \\
\hline & Fore Arm & $38^{\circ}$ & 2 & & & \\
\hline & Wrist & $32^{\circ}$ & 3 & & & \\
\hline & Twist & - & 1 & & & \\
\hline & Muscle & & & 1 & & \\
\hline & Power & & & 0 & & \\
\hline Group & Dimensions & Angle & Score & $\begin{array}{c}\text { Table } \\
\text { B }\end{array}$ & Score D & \\
\hline \multirow{5}{*}{ B } & Neck & $29^{\circ}$ & 3 & \multirow{3}{*}{3} & \multirow{5}{*}{4} & \\
\hline & Back & $19^{\circ}$ & 2 & & & \\
\hline & Feet & $87^{\circ}$ & 1 & & & \\
\hline & \multicolumn{3}{|l|}{ Muscle } & 1 & & \\
\hline & \multicolumn{3}{|l|}{ Power } & 0 & & \\
\hline
\end{tabular}

\section{Improvement}

The use of a sanding machine was done by sitting in a chair. Dimension is done only on the front side of the sanding machine, because it is adjusted to the use. The engine dimension data of the ideal chair dimensions were adapted in Kusumawati's research (2011).

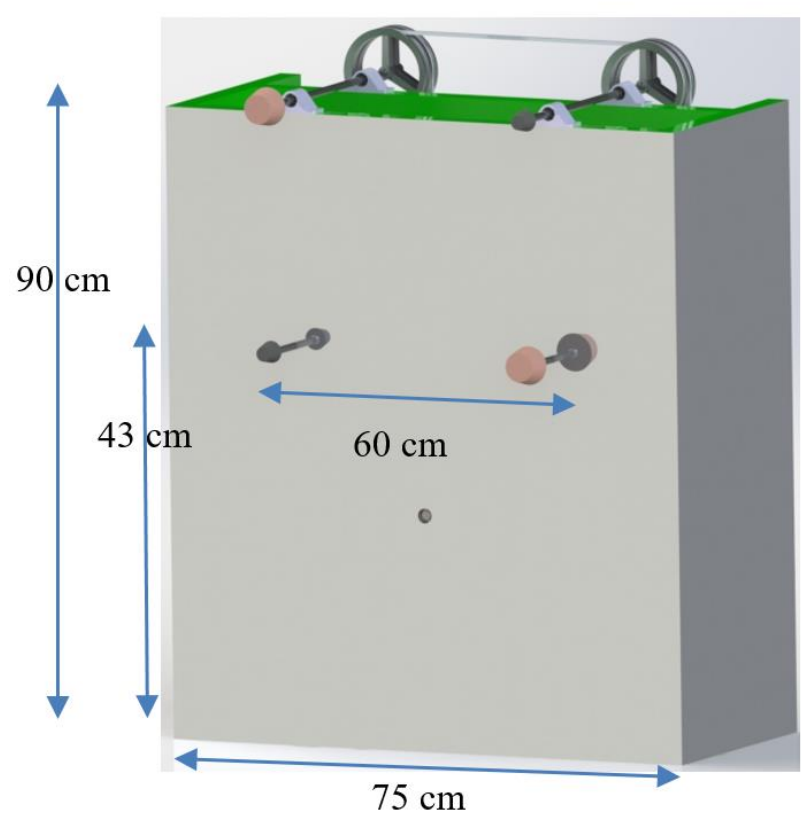

Figure 3. Sanding machine design improvements. 


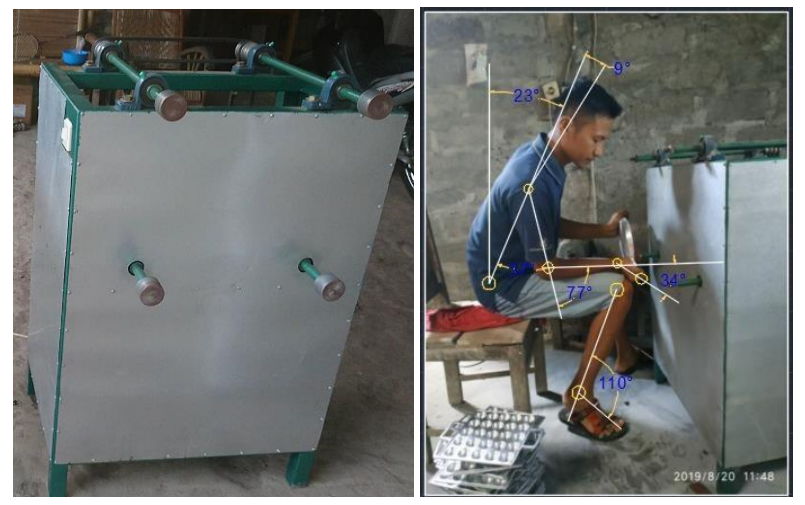

Figure 4. The operator's body position angle.

Table 5. REBA angle dimensions for sanding machine operators.

\begin{tabular}{|c|c|c|}
\hline Grup & Dimensions & Angle \\
\hline \multirow{4}{*}{ A } & Neck & 9 \\
\hline & Back & 23 \\
\hline & Knee & 110 \\
\hline & Load & 0 \\
\hline \multirow{3}{*}{$\mathrm{B}$} & Upper Arm & 37 \\
\hline & Forearm & 77 \\
\hline & Wrist & 34 \\
\hline
\end{tabular}

Table 6. REBA score on the sanding machine operator's work posture.

\begin{tabular}{|c|c|c|c|c|c|c|c|}
\hline Group & Dimensions & $\frac{0}{80}$ & 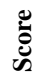 & $\begin{array}{c}\text { Table } \\
\text { A }\end{array}$ & $\begin{array}{c}\text { Score } \\
\text { A }\end{array}$ & $\begin{array}{c}\text { Score } \\
\text { C }\end{array}$ & $\begin{array}{l}\text { Score } \\
\text { REBA }\end{array}$ \\
\hline \multirow{4}{*}{ A } & Neck & $9^{\circ}$ & 1 & \multirow{3}{*}{2} & \multirow{4}{*}{2} & \multirow{9}{*}{2} & \multirow{10}{*}{3} \\
\hline & Back & $23^{\circ}$ & 3 & & & & \\
\hline & Knee & $110^{\circ}$ & 1 & & & & \\
\hline & \multicolumn{3}{|l|}{ Load } & 0 & & & \\
\hline Group & Dimensions & $\frac{0}{30}$ & ग्ँ & $\begin{array}{c}\text { Table } \\
\text { B }\end{array}$ & $\begin{array}{c}\text { Score } \\
\text { B }\end{array}$ & & \\
\hline \multirow{5}{*}{ B } & Upper Arm & $37^{\circ}$ & 2 & \multirow{3}{*}{2} & \multirow{4}{*}{2} & & \\
\hline & Lower Arm & $77^{\circ}$ & 1 & & & & \\
\hline & Wrist & $34^{\circ}$ & 2 & & & & \\
\hline & \multicolumn{3}{|l|}{ Coupling } & 0 & & & \\
\hline & \multicolumn{5}{|c|}{ Activity Score } & 1 & \\
\hline
\end{tabular}

Table 7. RULA angle dimensions for sanding machine operators.

\begin{tabular}{cll}
\hline Group & Dimensions & Angle \\
\hline \multirow{4}{*}{ A } & Upper Arm & 37 \\
& Lower Arm & 77 \\
& Wrist & 34 \\
& Twist & 0 \\
\hline \multirow{3}{*}{ B } & Neck & 9 \\
& Back & 23 \\
& Feet & 110 \\
\hline
\end{tabular}

Based on A and B score, it can be seen the value of the $\mathrm{C}$ score is equal to 2 . To get the REBA score, by summing the results of the $\mathrm{C}$ score that is equal to 2 with an activity score of 1 , then the results obtained score of 3.

Table 8. RULA score of sanding machine operator posture.

\begin{tabular}{|c|c|c|c|c|c|c|}
\hline Group & Dimensions & Angle & Score & $\begin{array}{c}\text { Table } \\
\text { A }\end{array}$ & $\begin{array}{c}\text { Table } \\
\text { C }\end{array}$ & $\begin{array}{l}\text { Score } \\
\text { RULA }\end{array}$ \\
\hline \multirow{6}{*}{ A } & Upper Arm & $37^{\circ}$ & 2 & \multirow{4}{*}{3} & \multirow{6}{*}{4} & \multirow{12}{*}{4} \\
\hline & Fore Arm & $77^{\circ}$ & 1 & & & \\
\hline & Wrist & $34^{\circ}$ & 3 & & & \\
\hline & Twist & - & 1 & & & \\
\hline & \multicolumn{3}{|l|}{ Muscle } & 1 & & \\
\hline & \multicolumn{3}{|l|}{ Power } & 0 & & \\
\hline Group & Dimensions & Angle & Score & $\begin{array}{c}\text { Table } \\
\text { B }\end{array}$ & $\begin{array}{c}\text { Score } \\
\text { D }\end{array}$ & \\
\hline \multirow{5}{*}{ B } & Neck & $9^{\circ}$ & 1 & \multirow{3}{*}{3} & \multirow{5}{*}{4} & \\
\hline & Back & $23^{\circ}$ & 3 & & & \\
\hline & Feet & $110^{\circ}$ & 1 & & & \\
\hline & \multicolumn{3}{|l|}{ Muscle } & 1 & & \\
\hline & \multicolumn{3}{|l|}{ Power } & 0 & & \\
\hline
\end{tabular}

Based on data processing using RULA, the $\mathrm{C}$ score in group $\mathrm{A}$ is 4 and the $\mathrm{D}$ score in group $\mathrm{B}$ is 4 . By looking at the grand score table based on $\mathrm{C}$ and $\mathrm{D}$ scores, the RULA score is 4.

\section{CONCLUSION}

From the analysis and results of the improvements obtained, it can be concluded; The sandpaper machine operator's posture has a REBA score of 3 with a level 1 action with a low level of risk, whereas the RULA score has a score of 4 with action level 2 with moderate risk level. This result shows that the design of sandpaper machine improvement is effective in reducing the risk of injury to low back pain operators, and can also speed up the processing time in its use without the need to change of the coarse and fine sandpaper eyes.

\section{REFERENCES}

Hignett, S. and McAtamney, L. (2000) Rapid Entire Body Assessment (REBA). Applied Ergonomics, 31, 201-205.

Kusumawati, Intan. 2011.Usulan Perancnagan Ulang Meja Kursi Baca Berdasarkan Aspek Fungsi Dan Kenyamanan Sesuai Kebutuhan Pengguna Perpustakaan (Studi kasus Di Kantor Arsip dan Perpustakaan Kabupaten Klaten). Surakarta: Universitas Sebelas Maret Surakarta.

Lueder, R., (1996), A Proposed RULA for Computer Users, Procceding of the Ergonomic Summer Workshop, San Francisco. 
McAtamney, L. and Corlett, E.N., (1993), "RULA: A Survey Based Method for the Investigation of Work Related Upper Limb Disorders", Applied Ergonomics, 24(2).91-99.

Prasetyo. (2012). Fasilitas Kerja dengan Perbaiakan Postur Kerja Pada Aktivitas Manual Handling Menggunakan Analisis
Metode Rapid Entire Body Assessment (REBA) dan Ovako Working Posture Anlysis System(OWAS) Studi Kasus Perusahaan Tempo Pedro Yogyakarta. Yogyakarta: UIN Sunan Kalijaga Yogyakarta. 
THIS PAGE INTENTIONALLY LEFT BLANK 